\title{
EFFECT OF ACCESS TO ICT ON THE USE OF INTERNET AMONG FARMERS IN SOUTH EAST NIGERIA
}

\author{
*OKWUSI, M. C AND **EKUMANKAMA, 0.0 \\ *National Root Crops Research Institute, Umudike, P.M.B. 7006, Umuahia, Abia State \\ **Department of Agricultural Extension and Rural Sociology, \\ Michael Okpara University of Agriculture, Umudike, Abia State. \\ Corresponding author's Email: mosesokwusi@yahoo.com
}

\begin{abstract}
A study was conducted on effect of access to information and communication technology on the use of internet among farmers in South East Nigeria. A structured interview schedule was used to collect data from 270 respondents from the study area. Data analysis was by the use of mean scores and simple regression. The study found that internet use correlated positively and significantly with accessibility, with a t-value of 3.462. The implication of this finding is that accessibility to ICTs will influence internet use. There is no doubt that usage of extent ICT such as internet is a function of awareness of the type of ICT available and needed for extension. Based on this it is recommended that public awareness on the use of ICT will enhance usage to a very large extent and should be strongly encouraged.
\end{abstract}

Key words: access internet use, farmers

\section{INTRODUCTION}

The world today is an information society. Information is increasingly used in all aspects of human activities and many technologies assist in providing information in a timely manner. Yet while information has always been indispensable in processes of political, economic and social development, the way that information is accessed, used and controlled today by information users are highly debated and extent of use among farmers in Nigeria is not known. In Nigeria, the information technology approach is gradually spreading and obviously will take time to be fully integrated into the agricultural systems, (Adesope et al., 2007). There is much discussion about the digital divide; in which some members of society, or areas of world are left behind others who have ready access to advanced ICTs. ICTs are foundation of the new global information-based economy. These dramatic changes have reached a new level in the 1990s. Of particular importance is the mass popularization of the internet, which has a worldwide user population estimated at many tens of millions (58 million in United States and Canada alone) and is growing fast.

At the end of 1999, all African countries were connected to the internet except for Eritrea. Public information campaigns about using the technology have multiplied, and national chapters of the Internet Society, a global organization concerned with evolution of communication protocols, have been established around the continent (Vittin, 2000). However, disparities in access and use of the Internet exist among African nations. As just mentioned, use in South Africa is highest, followed by Sub-Saharan Africa and then Maghreb countries and southern Africa. Within nations, although there are some exceptions, the Internet is only present in the capital or principal cities. The typical African "Internaut" is a young man, very well-educated, who belongs to the social and economic elite.

The estimated number of Internet users in Africa in 2007, is 33 million, which represents $3.6 \%$ of the internet users in the world. Excluding South Africa (and the North African countries of Morrocco, Algeria, Tunisia and Egypt, which have higher internet usage figures), the penetration of internet in Sub-Saharan African countries is an average of $2 \%$. 
Yet, internet use is growing fast in Africa: more than $600 \%$ for the whole Africa, over the period from 2000 to 2007. This can be compared with the total world internet usage growth, which was just over 200\% in the same period (Internet World Stats 2007a). The number of internet users in a country can be considered a "digital indicator" of the adoption of ICTs in society, and the integration into the global networked economy.

Table 1: Population per country, number of internet users and penetration: percentage of internet users relative to the total population

\begin{tabular}{|c|c|c|c|c|}
\hline & Population in 2007 & $\begin{array}{l}\text { Internet users } \\
\text { recent data }\end{array}$ & most & Penetration \\
\hline Total World & 6.574 .666 .417 & 1.114 .274 .426 & & $16.9 \%$ \\
\hline USA & 301.967 .681 & 211.108 .086 & & $69.9 \%$ \\
\hline China & 1.317 .431 .495 & 162.000 .000 & & $12.3 \%$ \\
\hline Netherlands & 16.447 .682 & 12.060 .000 & & $73.3 \%$ \\
\hline Total North Africa & 153.156 .098 & 12.805 .000 & & $8.4 \%$ \\
\hline South Africa & 49.660 .502 & 5.100 .000 & & $10.3 \%$ \\
\hline SSA & 736.925 .602 & 15.871 .800 & & $2 \%$ \\
\hline
\end{tabular}

(Source: Internet World Statistics, 2007a and 2007b).

Advanced telecommunication networks, computers, and related systems increasingly permeate every economic sector and help business of all kinds to enhance their organizational efficiency and competitiveness while providing customers better goods and services at lower price. But due to difficulties in paying for and managing these technologies, developing countries have often been unable to reap all the many benefits they offer, because ICTs can serve so many economic needs, countries without access to them will be at loss (Garcia, 2002). Ownership of computers and modems in rural areas is still low. And even when there is computer ownership, there is often little understanding of the services, no skill in configuring modems and access techniques and no enough training is available.

Egbokhari (2004) opined that socio cultural forces interact with ICTs or technologies in general to determine the direction of human progress and extent of use. Whether or not ICTs will revolutionize existing forms of organization and agricultural information transfer or reinforce existing power configurations depends on the interaction of a number of forces outside it. The use of ICTs in agricultural information dissemination among our rural farmers will no doubt increase their standard of living and economic development of the nation. This study therefore determines the effect of access to ICT on the use of internet among farmers in South East Nigeria.

\section{Hypothesis}

$\mathrm{H}_{\mathrm{O}}$ : There is positive relationship between the accessibility to ICTs and the use of agricultural information among farmers in the study area.

\section{METHODOLOGY}

The study was conducted in southeast agro ecological zone of Nigeria. The choice was predicated upon the high agricultural potential large farming and trading population as well as abundant natural resources, which maximum utilization could be guaranteed through the effective use of ICTs. The South East agricultural zone of Nigeria lies between latitudes $4^{\circ} 20^{\prime}$ and $7^{\circ} 25 \mathrm{~N}$ and longitudes $5^{\circ} 25^{\prime}$ and $8^{\circ} 51 \mathrm{E}$. It occupies a land area of about $109,524 \mathrm{~km}^{2}$, which represent about $11.86 \%$ of the total land area of Nigeria (Tewe et al., 2003). This area lies mainly on plains under $200 \mathrm{~m}$ above sea level. It is bounded on the South by bight of Bonny, on the East by the Republic of Cameroon, on the West by river Niger and on the North by Benue State (Monanu, 1975). The zone has a population of about 1.892 
million or $21.48 \%$ of the total population of Nigeria (NPC, 1991). The rural population accounts for about $60 \%$ with a population density of 173 people per square kilometer being one of the most thickly populated agricultural zones in Nigeria (Iloka and Anuebunwa, 1996).

There are nine states within the South East agricultural zone, namely, Abia, AkwaIbom, Anambra, Cross River, Enugu, Imo, Rivers, Bayelsa, and Ebonyi states. About 60-70\% of the inhabitants are engaged in agriculture. They are mainly engaged in crop farming except the riverie areas who are primarily fishermen (Unamma. et al., 1985). The total arable land in the zone is about 5.8 million hectares which averaged 0.31 hectares per person. The forest reserve account for about 5.4\% - 4.5\% and 26.4\% of the total land areas of Cross River, Rivers, Anambra and Akwa-Ibom States respectively. The average farm household size is seven members with farm sizes ranging from 1 hectare - 1.5 hectare per farm family. The farm activities provide about $60-70 \%$ of the household income, food crop production is the predominant agricultural activity except for the reverie areas. Capital cropping systems are the yam and cassava based cropping systems with the mixed cropping pattern dominating. The yam based cropping system consists of the yam as the hub crop and a number of minor crops. For example, yam/melon/maize/telfaira/okro/aerialyam followed by cassava/ yam/melon/maize/telfaira/okro/aerial yam/cocoyam. The minor crops are introduced and harvested by the womenfolk (Ekwe, 2004). The zone accounts for 36\%, 53\%, 70\%, and 17\% of the total national yam, cassava, cocoyam, rice maize production respectively (NARP, 1995).

\section{Sampling Procedure}

The respondents involved in the study were randomly selected from three states in the study area since all the states are fully engaged in agricultural production. The states included Anambra, Abia and Akwa Ibom States respectively. Three agricultural zones were randomly selected from the states apart from Abia State with only three zones. The selected zones were Aba, Umuahia and Ohafia in Abia state; Ikot Ekpene, Uyo and Eket in Akwa Ibom state and Awka, Onitsha and Anambra in Anambra state. From the three agricultural zones, one block was randomly selected. Also, from each block one circle was randomly selected and thereafter, 30 farmers each were also selected randomly from a list of farmers complied by the ADP staff. This implies that 90 farmers were interviewed in each state giving a total of 270 farmers from the three states. A total of 270 respondents were drawn from 9 circles of the three states. Nine ADPs staff were recruited and thoroughly trained in the administration of well designed interview schedule; working under researcher's supervision. One set of structured interview schedule was developed and used for data collection. Descriptive and inferential statistics were employed in data analysis.

\section{Hypothesis:}

There is positive relationship between the accessibility to ICT (internet) and the use of agricultural information among farmers in the study area.

\section{Relationship between Accessibility and use of ICT}

Table 2 shows that the exponential functional form was chosen as lead equation. Internet use correlated positively and significantly with accessibility, with a t-value of 3.462. The implication of this finding is that accessibility to ICTs will influence internet use. 
Journal of Agriculture and Social Research (JASR) VOL. 10, No. 2, 2010

Table 2: Simple Regression of Relationship between Accessibility and use of ICT

\begin{tabular}{lllll}
\hline & Exponential log & Double log & Semi log & Linear \\
\hline Constant & 1.329 & 6.074 & 1.369 & 5.943 \\
& $(13.717)^{*}$ & $(7.015)^{*}$ & $(0.512)^{*}$ & $(9.180)^{*}$ \\
Internet use & $6.880 \mathrm{E}-02$ & 1.150 & 0.194 & 0.380 \\
& $(3.462)^{*}$ & $(1.765)^{*}$ & $(1.981)^{*}$ & $(2.860)^{*}$ \\
$\mathrm{R}^{2}$ & 0.654 & 0.609 & 0.603 & 0.490 \\
$\mathrm{~F}-$ ratio & 11.989 & 3.115 & 3.926 & 8.181 \\
\hline
\end{tabular}

Source: Regression result of survey data, 2008

Figures in parenthesis represent t-radio

*Significant at 0.05 level

There is no doubt that usage of extent ICT such as internet is a function of awareness of the type of ICT available and needed for extension. This is why public awareness on the application of the several useful ICTs is inevitable. CTA (2002), posited that the need for instituting a public awareness strategy of intensive consultations with clients and other stakeholders cannot be overemphasized. Public awareness on the use of ICT will enhance usage to a very large extent.

\section{CONCLUSION AND RECOMMENDATIONS}

The study concludes that accessibility to ICTs influence internet use among farmers in South East Nigeria. Based on this it is recommended that public awareness on the use of ICT will enhance usage to a very large extent and should be strongly encouraged.

\section{REFERENCES}

Adesope O.M., Asiabaka C.C and Matthews-Njoku, E. C. (2007). Problems affecting the use of information technologies as perceived by Extension Managers in Nigeria. In: A.C. Agumagu, et al., (eds) Contemporary issues in Agricultural Extension and development studies. Series one. Omoku: Molsyfem United Services

Adesope O. M., Asiabaka C.C., Agumagu A. C. (2007). Effects of personal characteristics of extension managers and supervisors on information technology needs in the Niger Delta area of Nigeria. International Journal of Education and Development using ICT. -Vol.3, No.2 (2007) p1.

C.T.A (2002). Public awareness. A manual for agricultural NGOs and research institutions in Africa. The Technical Centre for Agricultural and Rural Cooperation (CTA), Wageningen, The Netherlands

Egbokhare, F. O. (2004). Breaking Barriers: ICT. Language Policy and Development. Odua Printing and Publishing company. Ibadan Nigeria. P 1.

Ekwe, K. C. (2004). Factors Associated with utilization of Garri processing Technology in South Eastern Nigeria. Unpublished, Ph.D. Thesis, MOUA Umudike, Nigeria.

Internet World Stats 2007a, World Internet Users and Population Stats, Internet usage statistics - The Big Picture, Retrieved 26, July 2007 from http://www.internetworldstats.com/stats 1 . Htm. 
Journal of Agriculture and Social Research (JASR) VOL. 10, No. 2, 2010

Internet World Stats 2007b, Internet Usage Statistics for Africa. Retrieved 26 July 2007 from http://www.internetworldstats.com/stats Htm.

Monanu, P.C. (1975): Geographical Boundaries of Nigeria. University of Ife press Vol. I. No.2 P3.

National Agricultural Research Projects (NARP) (1995): National Agricultural Research Strategic plan for 1996-2010. Draft Report, NARP Ibadan, Nigeria

National Population Commission (NPC), (1991): Provisional Population Census Result. National Population Press, Lagos Nigeria.

Unamma, R.P.A, Odurukwe, S.O. Okere, H.E. Ene, L.S.O. and Okoh O.O. (1985): Farming System in Nigeria. Report of Benchmark survey of farming system of South East Agricultural Zone of Nigeria, NRCRI, Umudike Nigeria. PP 116

Vittin T. (2000) Overview: Opportunity and Challenges of the Internet in Africa. In Voice from Africa: Information and Communication Technologies. Pp 1-12.NGLS website (www.unsystem.org/ngls) 